\title{
MODELING WATER QUALITY IN RIVERS: A CASE STUDY OF BEYLERDERESI RIVER IN TURKEY
}

\author{
YUCEER, M. $^{1^{*}}-\operatorname{COSKUN,~M.~A.~}{ }^{1}$ \\ ${ }^{I}$ Inonu University \\ Department of Chemical Engineering, Faculty of Engineering, Inonu University, 44280 \\ Malatya, Turkey \\ (phone: +90-422-377-4753; fax: +90-422-341-0046) \\ *Corresponding author \\ e-mail:mehmet.yuceer@inonu.edu.tr; \\ (phone:+90-535-468-7704; fax:+90-422-341-0046) \\ (Received 21 ${ }^{\text {st }}$ Sep 2015; accepted $23^{\text {rd }}$ Jan 2016)
}

\begin{abstract}
River pollution is a major environmental problem that has negative consequences for humans and wildlife alike. To prevent its consequences, the sources and severity of pollution must be determined by monitoring water quality in river basins, followed by the measures necessary to control the contamination. Models and computer simulation of water quality are important tools for predicting adverse effects of pollution along a stream, and they can help guide practical investments in stream health. In water quality models, parameters that are determined through optimization rather than through trial and error are required to ensure the reliability of the model. In this study, a continuous stirred tank reactor (CSTR) approach was used to model Beylerderesi stream as a dynamic model, and the kinetic parameters were determined through optimization. For the optimization step, the Sequential Quadratic Programming method was used. The model predictions indicated good agreement with experimental data. The Mean Absolute Percentage error values for dissolved oxygen and biochemical oxygen demand were calculated as $0.95 \%$ and $1.39 \%$, respectively. Statistical analysis showed differences between river and effluent samples for all parameters measured.
\end{abstract}

Keywords: river modeling, river water quality, dynamic simulation, parameter estimation, optimization

\section{Introduction}

Water pollution is gradually becoming a major issue in lakes and rivers. Water quality models can be useful tools for simulating and predicting pollutant transport (Bai et al. 2011; Huang et al., 2012; Wang et al., 2013). Surface water quality models have made enormous progress from estimating single factors of water quality to representing multiple drivers and aspects of water quality, from steady-state to dynamic models, from point source models to models that couple point and non-point sources, and from zero-dimensional models to one-, two-, and three-dimensional models (Wang et al., 2011). These models can be categorized by researchers based on water body types, the methods used to establish the models, the water quality coefficients, model properties, water quality components, reaction kinetics, and spatial dimension. However, all water quality models have constraints (Wang et al., 2013), so new models or modifications of existing models continue to emerge.

Mathematical models of water quality have been important in evaluating the impact of wastewater discharge into surface waters in recent years (Yetik et al., 2014). In addition, there have been major developments in water quality modelling for rivers. A review by Rauch et al. (1998) described the state of the art in river water quality modelling. The water quality models can be classified from many perspectives, according to model complexity, the simulation methods employed, and the number and type of water quality indicators incorporated. Cox (2003) noted that water quality modelling was a globally active area of research but that only 
few papers describe specific models. The majority of the papers reported applications of QUAL2E.

Some important surface water quality models, such as the Streeter-Phelps, QUASAR, QUAL, WASP, CE-QUAL-W 2, BASINS, and MIKE models have been widely used for studies (Fan et al., 2009; Morley, 2007). QUAL2EU, WASP7, and QUASAR models are the most suitable for simulating dissolved oxygen concentrations along rivers and streams (Kannel et al., 2011). Most advanced surface water quality models have been created by developed countries (The U.S. EPA website). A few surface water quality models that have been widely used are summarized in Table 1. Characteristic features of these models are also shown in Table 1.

Table 1. A list of select surface water quality models and their characteristics (Wang et al., 2013).

\begin{tabular}{|c|c|c|}
\hline Models & Model version & Characteristics \\
\hline Streeter-Phelps & $\begin{array}{l}\text { S-P model, Thomas BOD-DO } \\
\text { model, O'Connor BOD-DO model, } \\
\text { Dobbins-Camp BOD-DO model. }\end{array}$ & $\begin{array}{l}\text {-focuses on oxygen balance } \\
\text {-first-order decay of BOD } \\
\text {-one-dimensional steady-state models. }\end{array}$ \\
\hline QUAL & $\begin{array}{l}\text { QUAL I, QUAL II, QUAL2E, } \\
\text { QUAL2E UNCAS, QUAL 2K }\end{array}$ & $\begin{array}{l}\text {-suitable for dendritic rivers } \\
\text {-non-point source pollution } \\
\text {-one-dimensional steady-state or dynamic } \\
\text { models. }\end{array}$ \\
\hline WASP & WASP1-7 models & $\begin{array}{l}\text {-suitable for water quality simulation in } \\
\text { rivers, lakes, estuaries, coastal wetlands, and } \\
\text { reservoirs } \\
\text {-one-, two- or three-dimensional models. }\end{array}$ \\
\hline QUASAR & QUASAR model & $\begin{array}{l}\text {-suitable for dissolved oxygen simulation in } \\
\text { larger rivers } \\
\text {-one-dimensional dynamic model }\end{array}$ \\
\hline MIKE models & MIKE11, MIKE 21, MIKE 31 & $\begin{array}{l}\text {-suitable for water quality simulation in } \\
\text { rivers, estuaries, and tidal wetlands } \\
\text {-one-, two- or three-dimensional models. }\end{array}$ \\
\hline BASINS models & $\begin{array}{l}\text { BASINS 1, BASINS 2, BASINS } 3 \text {, } \\
\text { BASINS } 4,\end{array}$ & $\begin{array}{l}\text {-multipurpose environmental analysis } \\
\text { systems } \\
\text {-integrates point and non-point source } \\
\text { pollution } \\
\text {-suitable for water quality analysis at the } \\
\text { watershed scale. }\end{array}$ \\
\hline
\end{tabular}

The QUAL2E model is a flexible and accurate water quality model that has been widely applied in controlling pollution in watersheds and water quality management. This model has been used in medium-sized rivers to track the fate and transport of targeted pollutants (Ning et al., 2000; Pelletier et al., 2006; Zhu et al., 2015).

Karadurmus and Berber (2004) proposed a dynamic modelling strategy based on the QUAL2E model coupled with a parameter estimation technique. The suggested strategy assumes that a river reach can be modeled as a single continuous stirred-tank reactor (CSTR). For such reaches, the model predicts values and compares them to the field data for 10 quality metrics. Except for the total coliform, total chloride and $\mathrm{BOD}_{5}$, good agreement was obtained. In subsequent research, a reach was represented by a series of CSTRs rather than a single one, and the number of water quality model parameters identified was increased (Yuceer et al., 2007). Yuceer et al. (2007) also compared their own models to QUAL2E on the basis of experimental data collected in the Yesilirmak 
river in Turkey (Yuceer et al., 2007). In addition to the River Stream Dynamic Simulation (RSDS) software previously developed in MATLAB, our research group used the model by Yuceer et al. (2007) as the water quality model, and incorporated it into a GIS platform (Yetik et al., 2014).

In this study, serially connected CSTRs were used for the dynamic modeling of the water flow. Beylerderesi river is examined in a dynamic model, and the kinetic parameters were estimated by optimization.

\section{Materials and Methods}

\section{Field Observations and Data Collection}

For both field observations and data collection, the concentrations of water-quality parameters related to pollution in the river were determined either on site by portable analysis systems or in the laboratory from samples taken in the field. The experimental data for parameter estimation were obtained from sampling stations along the Beylerderesi River near the city of Malatya in Turkey. The concentrations of nine water quality variables that correspond to the state variables of the model and indicate the level of pollution in the river were determined either on-site by portable analysis systems or in the laboratory after careful conservation. For in situ measurements, four samples were taken and analyzed, and the mean of these four values was used. To determine BOD, samples were carefully preserved in the field and taken to the laboratory for analysis. Further details are presented in Karadurmus and Berber (2004).

Water quality constituents were measured at various locations along a $20 \mathrm{~km}$ section of the river. The sampling locations were matched to the water flow such that the volume element sampled at location zero (i.e., from the starting point at Şahnahan station) was followed downstream. This sampling scheme was designed to resemble tracking an element that is moving downstream at the same velocity as the main flow. After the starting point, samples were taken $0.5,11$ and $20 \mathrm{~km}$ downstream. The discharge site of an organized industrial zone II wastewater treatment plant is located $500 \mathrm{~m}$ downstream of the starting point, and a cesspool is discharged $11 \mathrm{~km}$ downstream of the starting point. Thus, this study models nutrient and contaminant discharged from these two sources. In the simulations, the addition of these discharges was considered to be a continuous disturbance to the system, and their water quality effects were determined. Table 2 reveals the properties of the Beylerderesi river immediately before and after the discharge sites.

Table 2. Properties of the Beylerderesi river immediately before and after the discharge sites

\begin{tabular}{l|c|c|c|c|c}
\hline & $\begin{array}{l}\text { Beylerderesi- } \\
\text { before } \\
\text { mixing }\end{array}$ & $\begin{array}{l}\text { organized } \\
\text { industrial zone } \\
\text { II wastewater } \\
\text { treatment plant } \\
\text { discharge }\end{array}$ & $11 . \mathrm{km}$ & $\begin{array}{l}\text { cesspool } \\
\text { discharge }\end{array}$ & $20 . \mathrm{km}$ \\
\hline Temperature $\left({ }^{\circ} \mathrm{C}\right)$ & 15.2 & 21.5 & 16.4 & 18.5 & 15.8 \\
$\mathrm{pH}$ & 8.11 & 8.27 & 8.19 & 7.70 & 8.38 \\
Conductivity $(\mu \mathrm{S} / \mathrm{cm})$ & 402 & 5520 & 945 & 871 & 1313 \\
Flow rate $\left(\mathrm{m}^{3} / \mathrm{s}\right)$ & 4.20 & 0.22 & 4.44 & 0.010 & 4.45 \\
Ammonia Nitrogen $(\mathrm{mg} / \mathrm{L})$ & 0.013 & 0.233 & 0.025 & 8.60 & 0.048 \\
Nitrite Nitrogen $(\mathrm{mg} / \mathrm{L})$ & 0.012 & 0.058 & 0.016 & 0.075 & 0.016
\end{tabular}




\begin{tabular}{l|c|c|c|c|c} 
Nitrate Nitrogen (mg/L) & 2.05 & 0.826 & 1.99 & 0.492 & 1.97 \\
Organic Nitrogen (mg/L) & 1.4 & 4.356 & 1.53 & 32.8 & 1.56 \\
Organic Phosphorus (mg/L) & 0.028 & 1.0 & 0.068 & 2.25 & 0.077 \\
Dissolved Phosphorus (mg/L) & 0.018 & 0.86 & 0.056 & 1.943 & 0.062 \\
Dissolved Oxygen (mg/L) & 9.17 & 7.5 & 8.9 & 5.10 & 9.0 \\
BOD $_{5}(\mathrm{mg} / \mathrm{L})$ & 11 & 56 & 10.3 & 28 & 8.0 \\
Total Chloride (mg/L) & 7.95 & 976 & 32.4 & 44.6 & 21.9 \\
\hline
\end{tabular}

Figure 1 shows the sampling stations used to collect the experimental data for dynamic simulation of the Beylerderesi river.

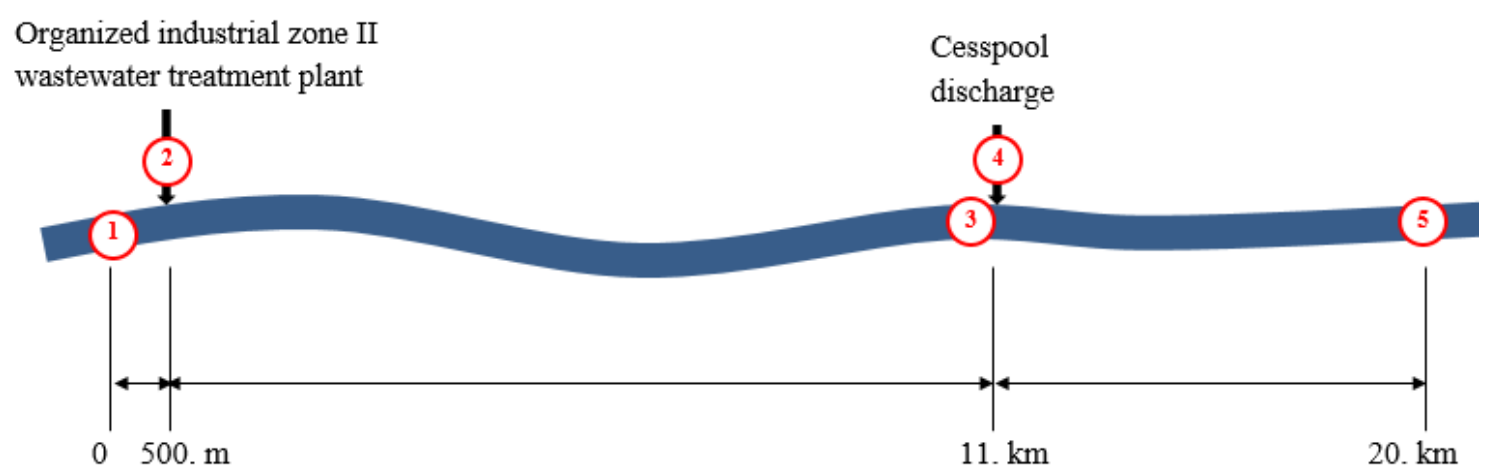

Figure 1. Sampling stations

Serially connected CSTRs are used to represent the flow of water and dissolved substances in dynamic modelling. Each reactor forms a computational element and is connected sequentially to similar elements upstream and downstream.

The following assumptions were employed for model development:

- The flow was well-mixed in cross sections of the river

- Dendritic streams were well-mixed

- There was constant channel cross section and stream flow

- The chemical and biological reaction rates were constant within the computational element.

All of the chemical, biological and physical reactions and interactions that might occur in the stream were considered. The modelling strategy employed in this study stems from that of the QUAL2E water quality model (Brown, 1987). DifferentialAlgebraic equations of the river model used in this study were taken from our previous study (Yuceer et al., 2007).

As representative elements of water quality from the perspective of environmental pollution, the following constituents were included in the model: ammonia nitrogen, nitrite nitrogen, nitrate nitrogen, organic nitrogen, biochemical oxygen demand, 
dissolved oxygen, organic phosphorous, dissolved phosphorus and chloride. The mass balance equation for each of these constituents was written, and several algebraic equations describing phenomena such as the conversion of different forms of nitrogen were included. The model thus simulates stream flow and 9 water quality constituents. Descriptive equations for the modeled properties and constituents were established in light of the stream's water volume (Yuceer et al., 2007).

A HACH-HQ40d multi-model digital portable oxygen meter was used for the analysis of dissolved oxygen. Ammonia nitrogen, nitrite nitrogen and nitrate nitrogen were measured with a HACH (Model DR3900) portable spectrophotometer. The Kjeldahl method was used to determine total nitrogen. The organic nitrogen was calculated as the difference between the total nitrogen and the sum of ammonia, nitrite and nitrate forms. Phosphorous was analyzed with colorimetric ascorbic acid amino reduction and molibdovanado phosphate in the same spectrophotometer. $\mathrm{BOD}_{5}$ analysis was performed in the laboratory, after careful transportation of the samples, with a manometric method in a $\mathrm{HACH}$ spectrophotometer. The chloride analysis was performed in a $\mathrm{HACH}$ spectrophotometer for chloride. The 9 state variables were determined from field measurements.

\section{Optimization Studies}

A nonlinear, constrained parameter estimation strategy has been incorporated into the simulation so that Sequential Quadratic Programming (SQP) can be used for optimization. SQP algorithms have had demonstrable success in constraint optimization (Yuceer et al., 2007; Yuceer et al., 2008; Balku et al., 2009; Atasoy et al., 2013). This method updates the Hessian matrix of the Lagrangian function, solves the quadratic programming subproblem and uses a line search and merit function calculation at each iteration. The estimation was based on minimizing the objective function defined in Eq. (1), the difference between the predictions and observed data during the transient period of observations.

$$
I=\sum_{i=1}^{n} \sum_{j=1}^{m}\left(y_{c_{i j}}-y_{o_{i j}}\right)^{2}
$$

Where $y_{c}$ is the computed value, $y_{o}$ is the observed value, $n$ is the total number of state variables and $m$ is the total number of observations in time for the particular station.

The model parameters of the Beylerderesi river were estimated via SQP optimization. A MATLAB code was written for parameter estimation. For the dynamic simulations, we used a stiff Runge-Kutta type explicit integrator along the river.

\section{Statistical Analysis of Data}

Statistical analyses are often used to characterize water quality in rivers. The physicochemical and bacteriological characteristics of various rivers have been analyzed (Abdul-Razak et al., 2009; Maglangit et al., 2014; Ewemoje et al., 2014; Khan and Nath, 2014, Yurtseven et al., 2016). 
To assess the contamination of the Beylerderesi River using physicochemical parameters, the data obtained were analyzed by means of the Statistical Package for Social Sciences (SPSS) version 22 (trial version). A one-way Analysis of Variance (ANOVA) was used to compare three or more means. A one-way ANOVA (alpha $=0.05$ ) was used to assess the difference between water quality sampling stations. ANOVA results were considered to be a significant difference at $\mathrm{p}<0.05$ for all sites.

\section{Results and Discussions}

The described model was based on the measurements of 9 state variables characteristic of streams and pollution loads (ammonium, nitrite, nitrate, and organic nitrogens, and dissolved organic phosphorus, 5-day biochemical oxygen demand, dissolved oxygen, and chloride). Model predictions and field data were compared along a $20 \mathrm{~km}$ reach of the river. In the simulations, the addition of two discharge sites was considered to be a continuous disturbance to the system, and their effect the water quality was determined. Figures $2-10$ show the profiles of nine pollutants, Ammonia-N, Nitrite-N, Nitrate-N, Organic-N, Organic-P, Dissolved-P, BOD 5 , Dissolved Oxygen (DO), Coliform and Chloride along a $20 \mathrm{~km}$ reach downstream from point-source inputs.

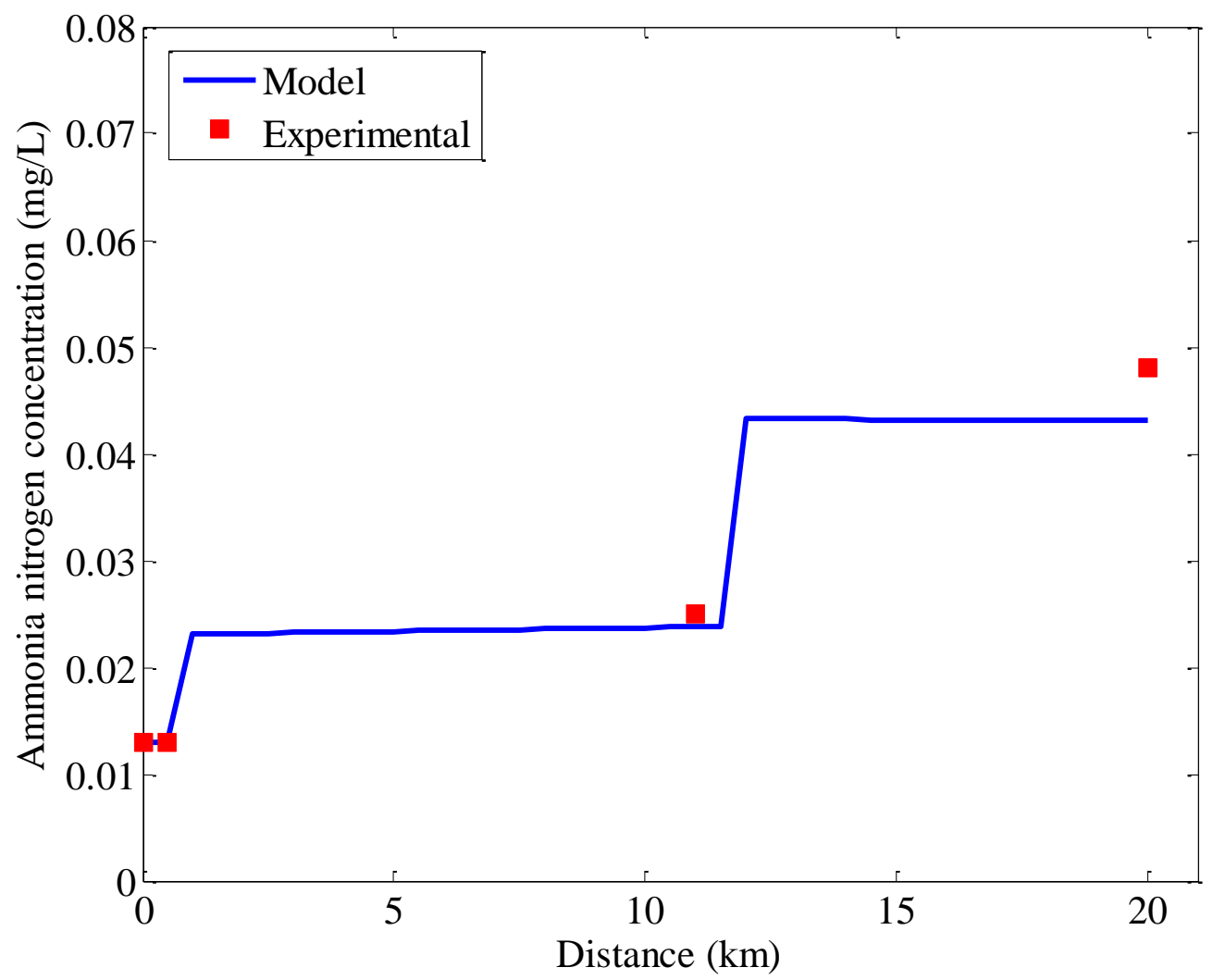

Figure 2. Ammonia nitrogen profile in a $20 \mathrm{~km}$ section 


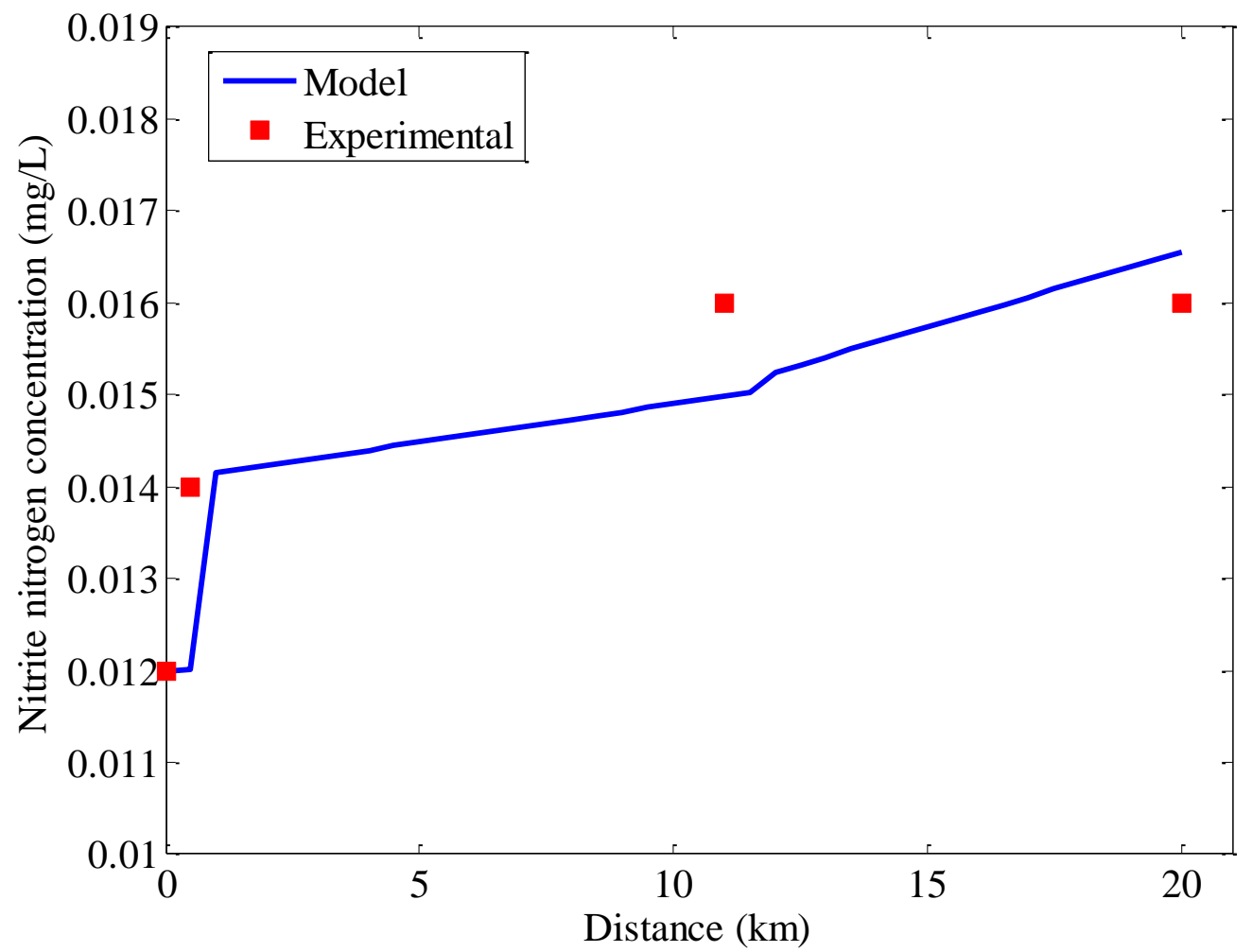

Figure 3. Nitrite nitrogen profile in a $20 \mathrm{~km}$ section

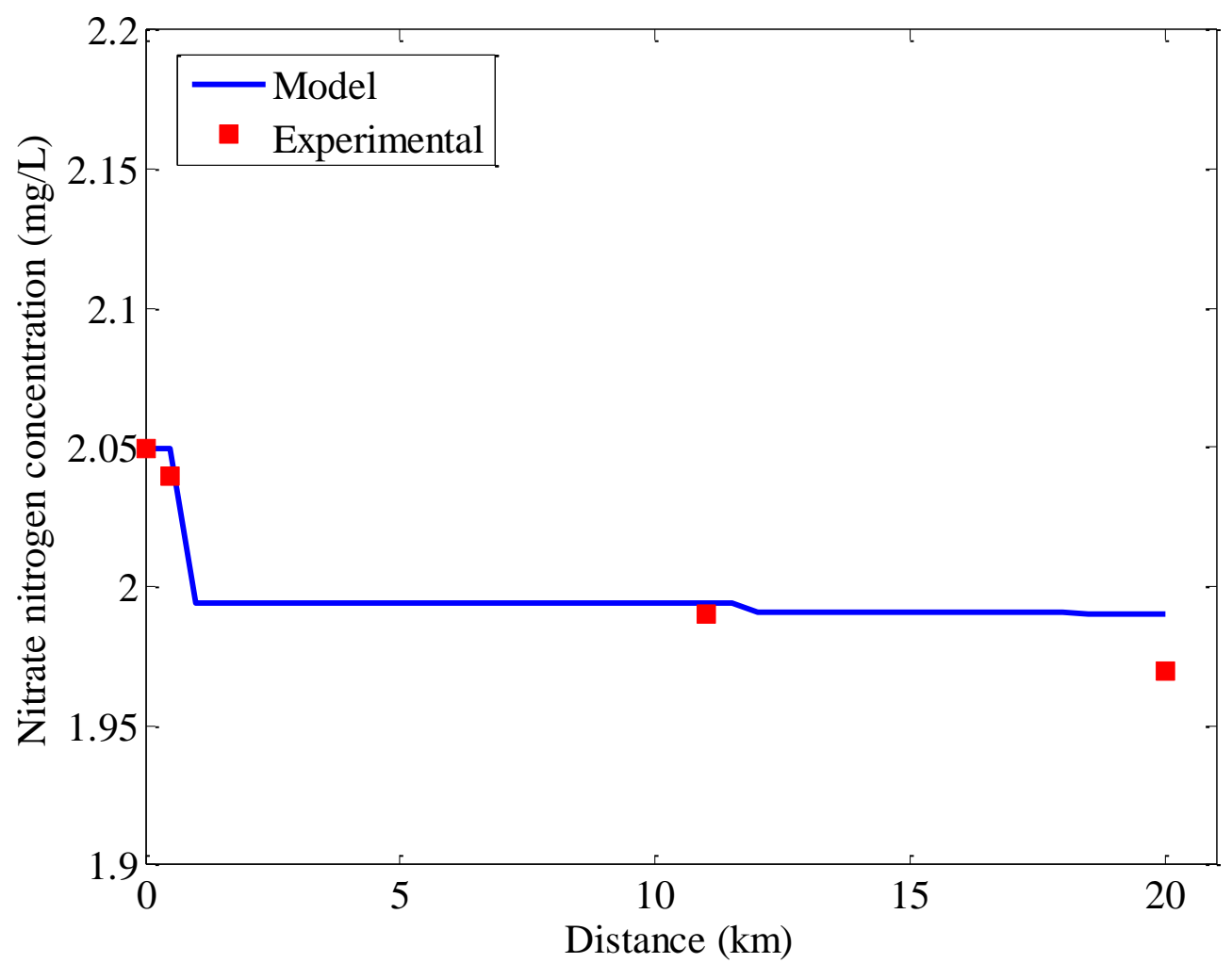

Figure 4. Nitrate nitrogen profile in a $20 \mathrm{~km}$ section

APPLIED ECOLOGY AND ENVIRONMENTAL RESEARCH 14(1): 383-395.

http://www.aloki.hu • ISSN 15891623 (Print) • ISSN 17850037 (Online) DOI: http://dx.doi.org/10.15666/aeer/1401_383395

(c) 2016, ALÖKI Kft., Budapest, Hungary 


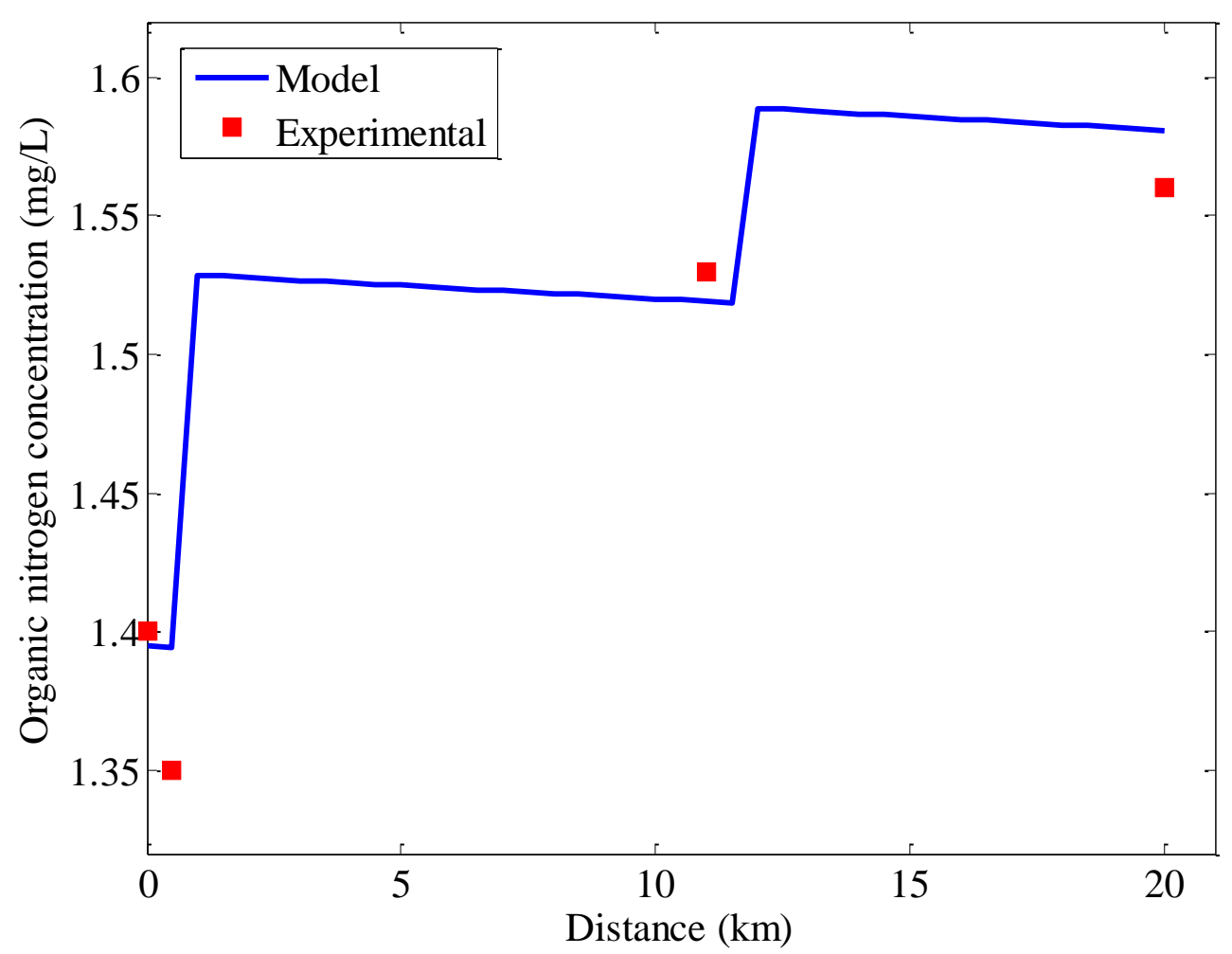

Figure 5. Organic nitrogen profile in a $20 \mathrm{~km}$ section

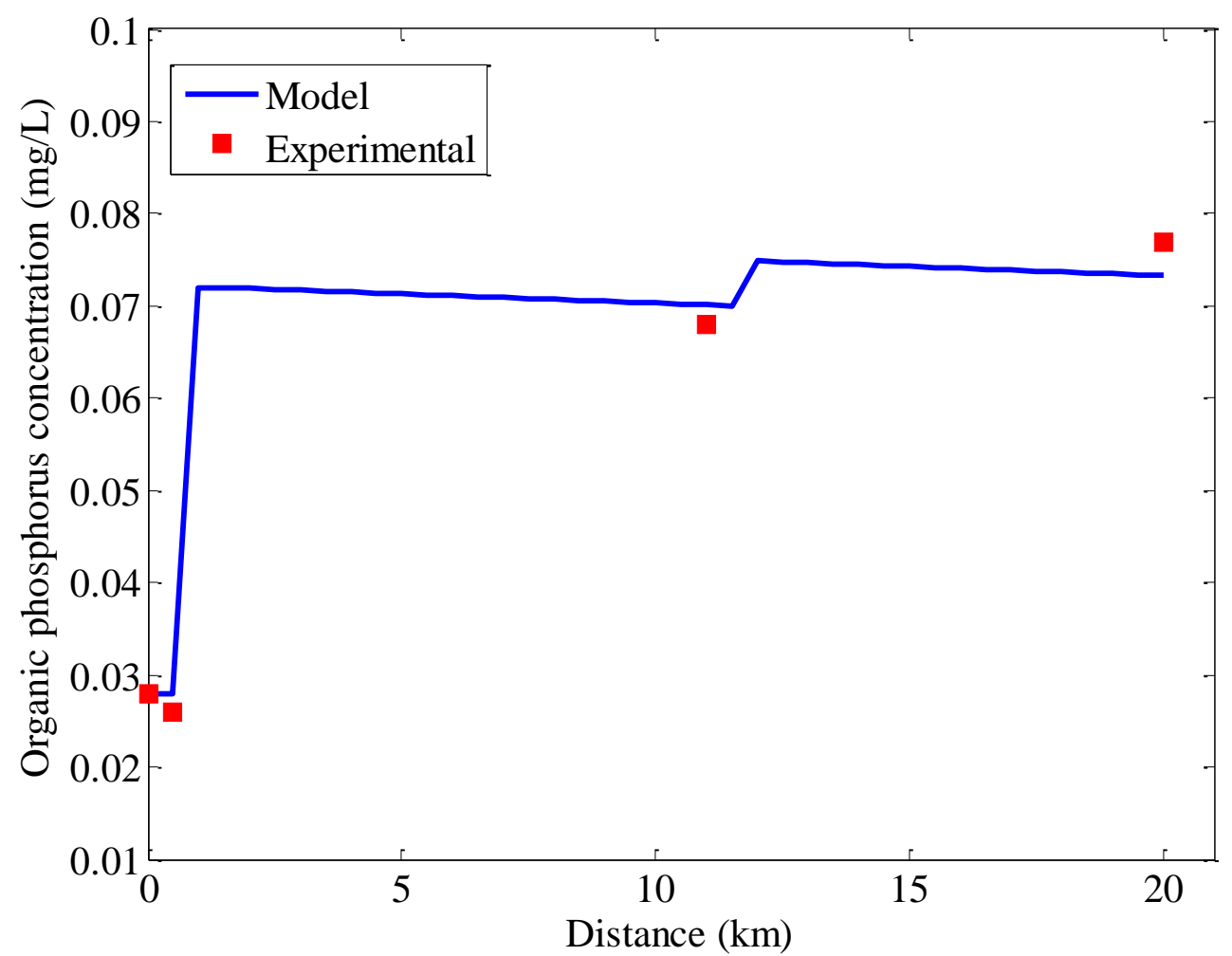

Figure 6. Organic phosphorus profile in a $20 \mathrm{~km}$ section

APPLIED ECOLOGY AND ENVIRONMENTAL RESEARCH 14(1): 383-395. http://www.aloki.hu • ISSN 15891623 (Print) • ISSN 17850037 (Online) DOI: http://dx.doi.org/10.15666/aeer/1401_383395 (c) 2016, ALÖKI Kft., Budapest, Hungary 




Figure 7. Dissolved phosphorus profile in a $20 \mathrm{~km}$ section

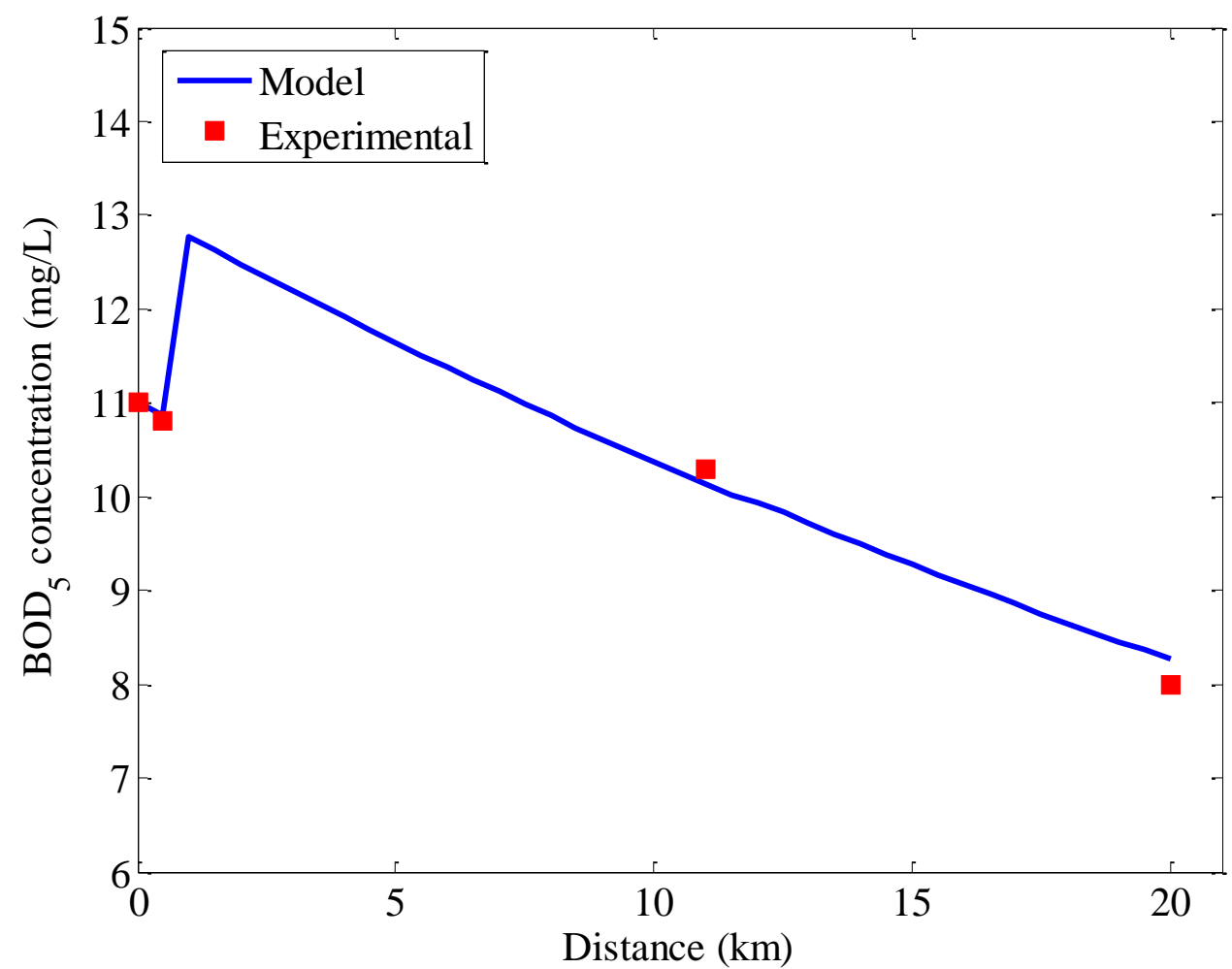

Figure 8. BOD5 profile in a $20 \mathrm{~km}$ section 


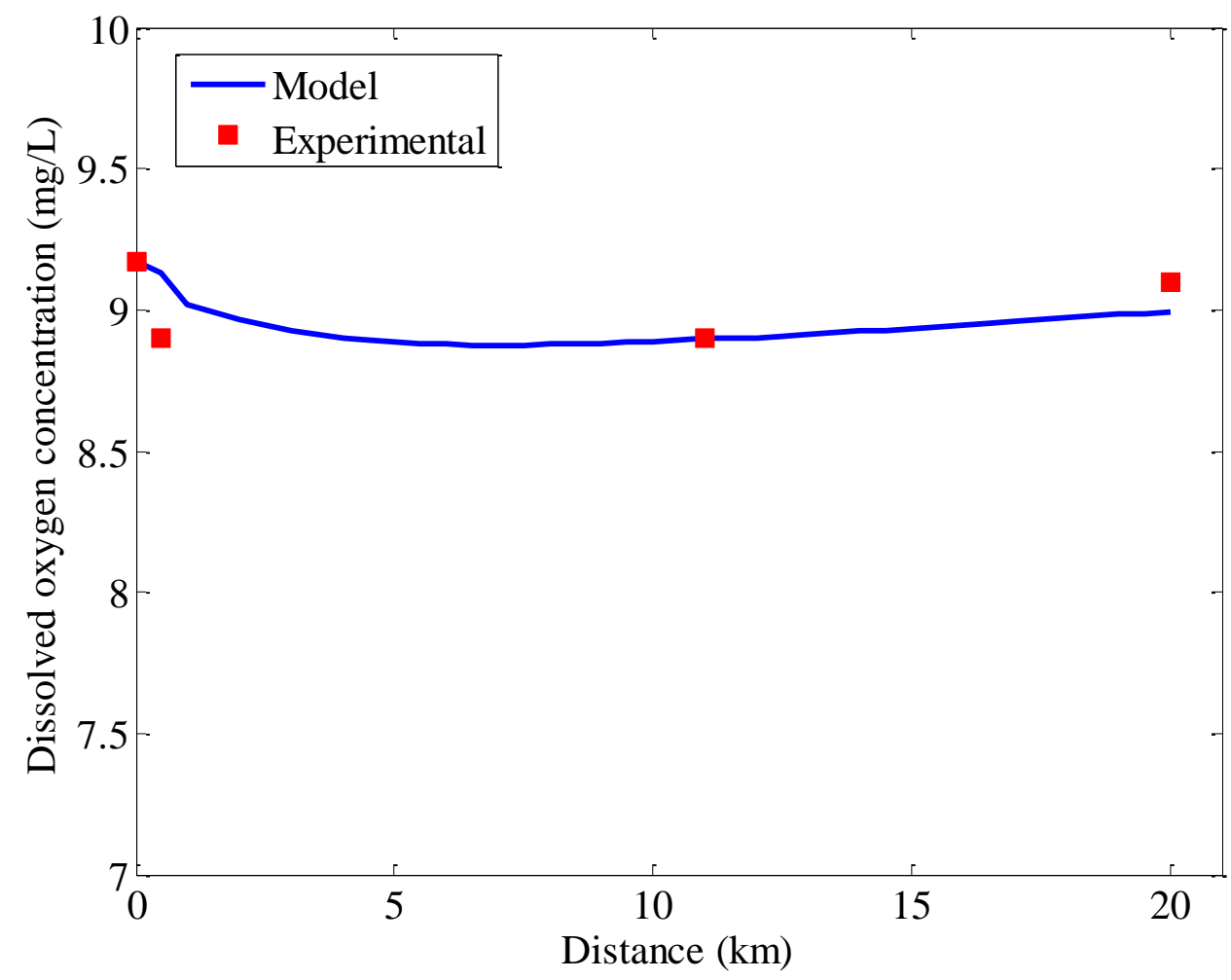

Figure 9. Dissolved oxygen profile in a $20 \mathrm{~km}$ section

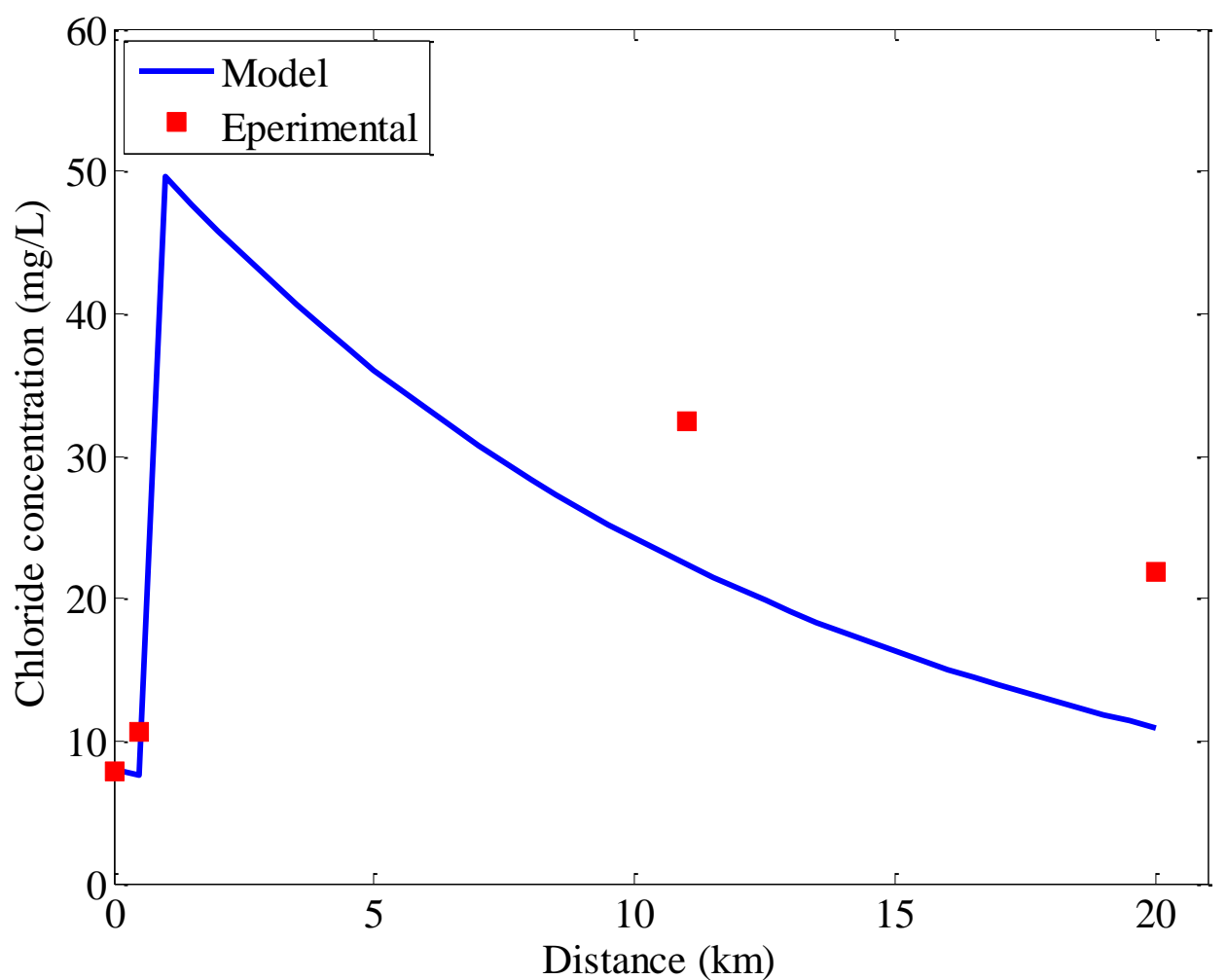

Figure 10. Chloride profile in a $20 \mathrm{~km}$ section

APPLIED ECOLOGY AND ENVIRONMENTAL RESEARCH 14(1): 383-395.

http://www.aloki.hu • ISSN 15891623 (Print) • ISSN 17850037 (Online)

DOI: http://dx.doi.org/10.15666/aeer/1401_383395

(c) 2016, ALÖKI Kft., Budapest, Hungary 
For statistical evaluation and comparison, Mean Absolute Percentage Error (MAPE) values were calculated for the dynamic simulation, as in Equation (2):

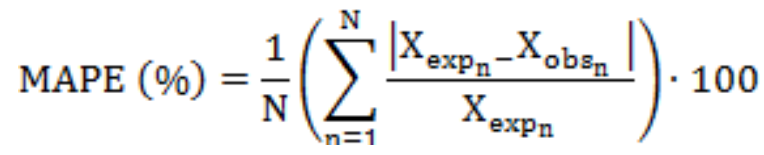

where $\mathrm{N}$ is the number of measurements, $\mathrm{X}_{\exp }$ is the experimental value, and $\mathrm{X}_{\mathrm{obs}}$ is the observed value.

A dynamic simulation and parameter estimation strategy were suggested in a previous study (Balku et al., 2009). According to this suggestion, modeling was based on the assumption that the segments of river between sampling stations were serially connected completely stirred tank reactors (CSTRs). In that research, the CSTRs provided automatically generated, reliable estimates of water quality model parameters without trial-and-error simulations. The results are given in Table 3 for the nine pollution variables considered. It can be seen from this table that the mean absolute average percentage error values were relatively small for most of the state variables. Therefore, the same dynamic simulation procedure was used for the current model, which offered a valuable model calibration tool for easily and reliably estimating the model parameters for river basins.

Table 3. Mean Absolute Percentage Error (MAPE \%) values for comparison of pollution variables

\begin{tabular}{l|l}
\hline Water Quality Variables & (MAPE, \%) \\
\hline Ammonia Nitrogen & 3.85 \\
Nitrite Nitrogen & 5.99 \\
Nitrate Nitrogen & 0.43 \\
Organic Nitrogen & 1.43 \\
Organic Phosphorus & 3.88 \\
Dissolved Phosphorus & 2.15 \\
BOD $_{5}$ & 1.39 \\
Dissolved Oxygen & 0.95 \\
Chloride & 27.4 \\
\hline
\end{tabular}

Statistical analysis of data is shown in Table A.l (Appendix). The table shows the values of the physicochemical parameters of the discharge from the wastewater treatment plant, the discharge of cesspool effluent and river water samples. There was significant variation in all parameters $(\mathrm{P}<0.05)$ between the river and effluents samples. The temperature, $\mathrm{pH}$, conductivity, ammonia nitrogen, nitrite nitrogen, organic nitrogen, organic phosphorus, dissolved phosphorus and total chloride levels significantly increased $(\mathrm{p}=0)$ in the downstream direction. Nitrate nitrogen, $\mathrm{BOD}_{5}$ and dissolved oxygen values decreased in the downstream direction.

Overall, the downstream parameter values were relatively higher than the upstream parameters, which could be attributed to wastewater and cesspool discharge containing organic waste entering the river. 


\section{Conclusions}

The mean absolute percentage errors obtained by comparing simulation results with field data along $20 \mathrm{~km}$ of stream indicated a good agreement between modeled values and the experimental data. Two of the most important indicators of stream health, its dissolved oxygen and biochemical oxygen demand, had average absolute error values of $0.95 \%$ and $1.39 \%$, respectively. The statistical analysis suggests that the measured values of the samples from the river were significantly different from those of the effluent samples.

This study may help predict the effects of planned industrial investments on water quality and help in the preparation of Environmental Impact Assessments.

Acknowledgements. This work was supported by the Inonu University Research Fund [Project Number: İ.Ü.B.A.P. 2011-17 and 2011-141].

\section{REFERENCES}

[1] Abdul-Razak, A., Asiedu, A. B., Entsua-Mensah, R. E. M. and deGraft-Johnson, K. A. A. (2009): Assessment of the water quality of the Oti river in Ghana. - West African Journal of Applied Ecology 15 pp.15.

[2] Atasoy, I., Yuceer, M., Berber, R. (2013): Optimisation of operating conditions in fedbatch baker's yeast fermentation. - Chemical and Process Engineering 34(1): 175-186.

[3] Bai, J., Cui, B., Chen, B., Zhang, K., Deng, W., Gao, H., Xiao, R. (2011): Spatial distribution and ecological risk assessment of heavy metals in surface sediments from a typical plateau lake wetland, China. - Ecological Modelling 222(2):301-306.

[4] Balku, S., Yuceer, M., Berber, R. (2009): Control vector parameterization approach in optimization of alternating aerobic-anoxic systems. - Optimal Control Applications and Methods 30(6):573-584.

[5] Brown, L. C. (1987): Uncertainty analysis in water quality modelling using QUAL2E, EPA/Technical Report Data, Athens, GA.

[6] Cox, B.A. (2003): A review of available in-stream water quality models and their applicability for simulating dissolved oxygen in lowland rivers. - The Science of the Total Environment 314-316: 335-377.

[7] Ewemoje, O.E., Ihuoma, S.O. (2014): Physicochemical changes in the quality of surface water due to sewage discharge in Ibadan, South-Western Nigeria. - Energy and Environment Research 4(1):55-61.

[8] Fan, S. F., Feng, M. Q., Liu, Z. (2009): Simulation of water temperature distribution in Fenhe reservoir. - Water Science and Engineering 2(2):32-42.

[9] Huang, L, Bai, J., Xiao, R., Gao, H., Liu, P. (2012): Spatial distribution of Fe, Cu, Mn in the surface water system and their effects on wetland vegetation in the Pearl River Estuary of China. - CLEAN-Soil, Air, Water 40(10): 1085-1092.

[10] Kannel, P. R., Kanel, S. R., Lee, S., Lee, Y-S., Gan, T. Y. (2011): A review of public domain water quality models for simulating dissolved oxygen in rivers and streams. Environmental Modeling and Assessment 16(2):183-204.

[11] Karadurmus, E. and Berber, R. (2004): Dynamic Simulation and Parameter Estimation in River Streams. - Environmental Technology 25(4): 471-479.

[12] Khan, S. Nath, S. (2014): Physiochemical analysis of river ganges at Mirzapur in Uttar Pradesh, India. - IOSR Journal of Applied Chemistry 7(12):2278-5736.

[13] Maglangit, F.F., Galapate, R. P., Bensig, E.O. (2014): Physicochemical-assessment of the water quality of Buhisan river, Cebu. - International Journal of Research in Environmental Science and Technology 4(2): 83-87. 
[14] Morley, N. J. (2007): Anthropogenic effects of reservoir construction on the parasite fauna of aquatic wildlife. - EcoHealth 4(4): 374-383.

[15] Ning, S.K., Chang, N.B., Yong, L. (2000): Assessing pollution prevention program by QUAL2E simulation analysis for the Kao-Ping River Basin, Taiwan. - Journal of Environmental Management 61(1):61-76.

[16] Pelletier, G.J.; Chapra, S.C.; Tao, H. (2006): QUAL2Kw-A framework for modeling water quality in streams and rivers using a genetic algorithm for calibration. Environmental Modelling \& Software 21: 419-425.

[17] Rauch, W., Henze, M., Koncsos, L. Reichert, P., Shanahan, P., Somlyody, L. and Vanrolleghem, P. (1998): River Water Quality Modelling: I. State of The Art. -IAWQ Biennial Int. Conf. Vancouver-Canada, 21-26.

[18] The US Environmental Protection Agency," http://water.epa.gov/scitech/datait/ models/basins/fs-basins4.cfm.

[19] Wang, Q., Li, S., Jia, P., Qi, C., Ding, F. (2013): A review of surface water quality models. - The Scientific World Journal Article ID 231768, 7 pages.

[20] Wang, Q., Zhao, X., Yang, M., Zhao, Y., Liu, K., Ma, Q. (2011): Water quality model establishment for middle and lower reaches of Hanshui river, China. - Chinese Geographical Sciences 21(6): 647-655.

[21] Yetik, M.K., Yuceer, M., Karadurmus, E., Semizer, E., Calimli, A., Berber, R. (2014): An interactive GIS-based software for dynamic monitoring of rivers. - Journal of Environmental Protection and Ecology 15(4): 1767-1778.

[22] Yuceer, M. Atasoy, I., Berber, R. (2008): A software for parameter estimation in dynamic models. - Brazilian Journal of Chemical Engineering 25(4): 813-821.

[23] Yuceer, M., Karadurmus, E. and Berber, R. (2007): Simulation of river streams: Comparison of a new technique to QUAL2E. - Mathematical and Computer Modelling 46(1-2): 292-305.

[24] Yurtseven, I., Serengil, Y., Pamukçu, P. (2016): Seasonal changes in stream water quality and its effects on macroinvertebrate assemblages in a forested watershed. - Applied Ecology and Environmental Research 14(1):175-188.

[25] Zhu, W., Niu, Q., Zhang, R., Ye, R., Qian, X., Qian, Y. (2015): Application of QUAL2K model to assess ecological purification technology for a polluted river. - Int. J. Environ. Res. Public Health 12(2):2215-2229.

\section{ELECTRONIC APPENDIX}

Appendix 1. Statistical analysis of data 